\title{
INTERRELIGIOUS DIALOGUE: AN ISLAMIC APPROACH
}

\author{
Mohammad Elius ${ }^{\mathrm{a}}$ \\ Issa Khan ${ }^{* b}$ \\ Mohd Roslan Mohd Nor ${ }^{\mathrm{c}}$ \\ ${ }^{a}$ Department of Islamic History and Civilization, Academy of Islamic Studies, University \\ of Malaya, Malaysia \\ ${ }^{a}$ Department of World Religions and Culture, University of Dhaka, Bangladesh \\ ${ }^{b}$ Department of Shariah and Management, Academy of Islamic Studies, University of \\ Malaya, Malaysia \\ ${ }^{c}$ Department of Islamic History and Civilization, Academy of Islamic Studies, University \\ of Malaya, Malaysia
}

\begin{abstract}
Dialogue among the followers of different religions is a necessary condition for promoting peace, tolerance, harmony, and religious co-existence in today's world. The purpose of this study is to examine the concept of interreligious dialogue from an Islamic point of view. The study is based on textual analysis and historical interpretation of the Qur'an and Sunnah. The research shows that the Qur'anic verses emphasise justice, diversity, and unity based on the origin of mankind. The Prophetic traditions (Sunnah) show equal treatment of both Muslims and non-Muslims. It inspires Muslims to behave honourably towards all irrespective of their religion. Finally, the study concludes that the teachings of the Qur'an and Sunnah constitute a model for promoting interreligious dialogue and harmony.
\end{abstract}

Keywords: Interreligious dialogue, Islamic approach, Qur'an, Sunnah, peace and harmony.

\footnotetext{
*Corresponding author: shahaalam83@gmail.com, issa@um.edu.my eISSN 2636-9265 (C) Centre for Civilisational Dialogue DOI: https://doi.org/10.22452/KATHA.vol15no1.1
} 


\section{Introduction}

An increasingly popular issue today is dialogue among the followers of different religions (Swidler, 2014; Elius et al., 2019). Human beings are living in a global world with diverse ethnicities, religions and cultures (Wani et al., 2015; Nor et al., 2018) and interreligious dialogue is vital for maintaining harmony and peaceful co-existence (Elius et al., 2019). There have been innumerable tragic events in history. The 9/11 attacks, Israel-Palestine conflict, aggression against Iraq, Afghanistan and Syria, Muslim-Buddhist conflicts in Thailand, the massacre of Rohingya Muslims in Myanmar, conflicts in Jammu-Kashmir are a handful of the conflicts that continue to ravage the world today (Gunaratna, 2015; Hasan, 2011).

It is believed that all religions teach love and sympathy for other human beings, yet many heinous acts have been perpetrated in the name of religion resulting in the casualties of many innocent people including women and children (Human Right Watch, 2016). Therefore, it is our duty to unite people of different religious and cultural backgrounds and make a meaningful contribution through interreligious dialogue for the greater interest of humanity (Islam, 2010). Interreligious dialogue can be considered an essential tool for reducing and mitigating interreligious tensions (Elius et al., 2019). History has recorded many initiatives of interreligious dialogue. Islam, being a universal religion, teaches love, tolerance and sympathy for other human beings (Nor et al., 2018) and Muslims have played a vital role in promoting interreligious harmony since the time of Prophet Muhammad (PBUH) (Elius et al., 2019).

The Holy Qur'an includes multiple examples of dialogue (Al-Qur'an 16:125; 5: 48; 49: 13). These dialogues include those between prophets and God, Angels and God, prophets and their people, even dialogue with the devil (Humaid, 2010). The Prophet Muhammad (PBUH) was a model for positive engagement even before his Prophethood (Ibn Hisham, 1955; Elius et al., 2019). That is why people used to call him al-Amin, 'the trustworthy', and asSadiq, 'the truthful' (Kurucan \& Erol, 2012; Nor et al., 2018). Islamic history bears many examples of positive interreligious relationships (Karim and Saile, 2009; Nor, 2012). However, today, 
Islam has been misunderstood and misinterpreted especially in the post-9/11 which sparked a sustained and ongoing hate campaign against Islam and Muslims (Considine, 2017). Nevertheless, several studies have sought to eliminate prevalent misunderstandings especially those advocated by Westerners (Kamali, 2009; Baker, 2009; Nor, 2008; Hasan, 2009; Hasan, 2011; Mandour, 2010; Haque, 2010; Elius et al., 2019). This study seeks to contribute to this response to mitigate interreligious tensions and promote interreligious harmony.

\section{Methodology}

This research adopted the qualitative method. It collected data from the primary sources of Islam, i.e. the Qur'an and Sunnah (the Prophetic tradition) in addition to reviewing several articles, books, and the opinions of contemporary religious scholars to understand the Islamic approach to interreligious dialogue.

\section{Defining Interreligious Dialogue}

The term 'dialogue' comes from Greek words, dia, "across" and legein, "to speak" (Doron, 2019). Dialogue is defined as discussion, talk, conversation and consultation between two or more groups or individuals with an intention to share and learn from one another for common wellbeing (Karim \& Saile, 2009; Elius et al., 2019). It is also defined as a process of communication through discussion (Kimball, 1991). It is not a debate through which one group wins by defeating the other. Interreligious dialogue refers to a positive relationship with mutual and cooperative attitudes among the followers of different religions. It is an assembly of mind and heart between the people of different religions for a common cause (Arinze, 1990). It is a discussion between the people of one religion and another on general or particular issues with a view to promoting peace and understanding (Elius et al., 2019). It is not a mutual imitation but, a mutual understanding for the common benefit. There is nothing to compromise one's religion and no need to agree with every aspect of other religions. It is simply an honest engagement in which the followers of different religions try to understand each 
other despite their religious differences (Kurucan \& Erol, 2012). Senin et al. (2013) refer to Al-Biruni's approach to the study and understanding of other religions as being unprejudiced while remaining steadfast in one's belief. So, in dialogue, each party will try to understand the position of others and correct their prejudiced ideas about another party as well as discuss the common areas of each religion (Mandour, 2010).

The common cause of interreligious dialogue is to gather the followers of diverse faiths and make a meaningful contribution to peaceful co-existence and interreligious harmony (Al-Masud and Elius, 2016; Elius et al., 2019). Hans Kung is quoted by Morgan (2011; Elius et al., 2019) as saying: "No peace among the nations without peace among the religions. No peace among the religions without dialogue between the religions. No dialogue between the religions without investigation of the foundations of the religions". Hambali (2015) characterises interreligious dialogue as "all positive, constructive inter-religious relations with individuals and communities of other faiths which are directed at mutual understanding and enrichment, in obedience to the truth and respect for freedom".

Two Arabic words are used in the Qur'an to convey the meaning of dialogue. The first is hiwar which means any discussion between two or more people that aims at correcting mistakes, putting forth arguments, establishing facts, rebutting specious arguments, or replying to false claims or views. The second is Jadal, which has the same general meaning as hiwar, but is used when the intention is to overcome the other party even when the argument against him is not convincing (Humaid, 2010).

Some Muslim scholars define dialogue as $D a$ 'wah which includes preaching Islamic teachings, promoting virtues and avoiding vices, diverting to a faith beneficial for them and helping them save divergence, transporting them from somewhere to somewhere else, and providing comprehensive knowledge to understand the purpose of life (Karim and Saile, 2009). Ismael Raji al-Faruqi, the prominent Islamic thinker, denotes dialogue as Da'wah and Mission and considers it an essential tool for Muslims and Christians (Al-Faruqi, 1998). It can be mentioned here that Islamic $D a$ 'wah is not only for promoting Islam as a religion but 
also for promoting human values for the common benefit of all. Diana Eck as mentioned by Sintang et al. (2012) identifies dialogue into six categories: parliamentary, theological, institutional, spiritual, inner and or dialogue of life. Parliamentary dialogue deals with a large assembly of interfaith discussion such as Chicago's World's Parliament of Religions in 1893 (Swamy, 2012, 35). Theological dialogue refers to the meeting of people from various religions for the discussion of theological and philosophical issues (Hambali, 2015). Institutional dialogue strives for establishing channels of communication among different religious communities through institutional means. Many international organisations have been promoting this dialogue (Al-Masud and Elius, 2016). Inner dialogue occurs when people study the religious scriptures of other religions and realise their inner meanings (Lysack, 2006).) Spiritual dialogue happens through the spiritual exchange of views of different religions, which is considered a means for spiritual development (Tan, 2001). Also, dialogue of life is an interaction between the followers of one religion and another in their daily life (Sintang et al., 2012).

\section{Islamic Concept of Interreligious Dialogue}

Although human beings are often identified by their ethnic, religious and cultural identities, yet their origin is one and same (Shehu, 2008). God commands all human beings not only to be responsive to Him but also the phenomena around them. So, dialogue between human beings is considered an integral part of innate disposition (fitra) (Kurucan and Erol, 2012). The Islamic greeting Assalamualaikum (peace be upon you), perpetuates peace. Prophet Muhammad (PBUH) is called Rahmatan lil Alamin (mercy for the whole world) (Al-Qur'an, 21: 107). Islam teaches that every human being has the right to choose and practice his or her religion. The Qur'an says: "for you your religion and for me my religion" (A1Qur'an, 109:6). So, Islam can never be imposed on anybody belonging to another religion. The Qur'an reminds the Prophet how to preach Islam by stating: "your responsibility is only conveying the Message" (Al-Qur'an, 13: 40). In another verse, God said, "If they turn away (O' Muhammad) then upon you is the responsibility 
to convey clearly" (Al-Qur'an, 18: 82). Al- Qurtubi (1964) asserts that Muslims have no right to impose their religion on anybody. They must provide freedom in selecting and practising religion. Another verse clarifies that accepting Islam depends on the choice of the individual: "And say, the truth is from your Lord, so let him believe who wills and let him disbelieve who wills" (Al-Qur'an, 18: 29).

According to Islam, there is no single law for all times. God sent His Messengers to every nation, and there were different Messengers for different nations. God did not make any distinction between the Messengers (Al-Qur'an, 22: 67; 2: 285). Muslims must believe in all the Prophets and Messengers of God as a fundamental requirement (Al-Qur'an, 4: 136; 4: 164). Islam warns of a humiliating punishment to those who believe in some prophets of God and deny others (Al-Qur'an, 4:150-151). Thus, the Qur'an advocates an inclusive approach. Islam is the continuation of all previously revealed religions. That is why Abraham (Prophet Ibrahim) was called a Muslim (Al-Qur'an, 3: 67). Jews and Christians are mentioned with honour in Islam. The Qur'an also approves the food of the Ahl al-Kitab (Jews and the Christians) for Muslims (Al-Qur'an, 5: 5). Although Islam refutes polytheism, it does not permit assaulting polytheists or seizing their properties. Rather, Islam has made it compulsory upon Muslims to ensure their safety (Al-Qur'an, 9: 6). In such a way, Islam has set a unique example of tolerance, sympathy and interreligious harmony. Prophet Muhammad (PBUH) put the Qur'anic guidance into practice. He used to visit the sick without considering their religious affiliation (Al- Tirmidhi, 1975). Based on his practice, Islamic history has many examples of peaceful relationships between Muslims and non-Muslims (Elius et al., 2019; Nor, 2012).

\section{The Qur'anic Explanation of Interreligious Dialogue}

There is no single country without diversity in the world (Wani et al., 2015; Islam, 2010). God created diversity for our benefit. The Qur'an states: "If Allah had willed, He would have made you a single community" (Al-Qur'an, 5:48). It can be understood from the verse mentioned above that the existence of different religions is 
part of God's plan. So, it is the responsibility of Muslims to accept diversity as a blessing of God and live with people of different religions, culture and ideologies in peace, harmony and cooperation (Kurucan \& Erol, 2012; Elius et al., 2019). The Holy Qur'an points to various examples of dialogue. It asks Muslims to show the best of manners and wisdom when calling the people of other faiths. The Qur'an says: "Invite (people) to the way of your Lord with wisdom and good words; and argue with them in ways that are best and most gracious. Indeed, your Lord is all knowing of those who have strayed from His path and who receive guidance" (Al-Qur'an, 16: 125). Wisdom, respectful conversation and gracious behaviour are vital for strengthening mutual relationship (Nor et al., 2018). God wants all human beings to be just in every aspect of life. One of the names of Allah is Al- 'Adil (the Just). If there is no justice, there is no goodness. As such, justice is a precondition for establishing a peaceful and prosperous society. That is why the Qur'an emphasises justice in dealing with the people of other religions, culture and ethnicity. The Qur'an states: 'O you who believe! Stand out for God, as witness to fair dealing, and let not the hatred of others to you make you swerve to wrong and depart from justice. Be just: that is next to piety: and fear God. For God is well acquainted with all that you do" (Al-Qur'an, 5: 8).

Justice, kindness and respectful behaviour can help strengthen human relationships. That is why the Qur'an also asks Muslims to show kindness and be just when dealing with one another regardless of their religions. The Qur'an says: “And He does not forbid you to deal kindly and justly with anyone who has not fought you for your faith or driven you out of your homes: God loves just" (Al-Qur'an, 60:8). Al- Tabari (2000) explains that Muslims must always be just and fair in dealing with others and maintain harmonious relationships unless non-Muslims show open hostility to Muslims. Ibn Kathir (1999; Elius et al., 2019) comments that Islam strictly prohibits Muslims to fight against those who do not consider Muslims their enemies and initiate fighting. The Qur'an reminds Muslims that all human beings irrespective of their religion, culture and ethnicity come from the same origin, "O mankind! Be careful of your Lord Who created you from a single soul and from it created its mate and from them twain hath spread a multitude of 
men and women" (Al-Qur'an, 4:1) and "O mankind! Verily we have created you of a male and a female and made you into races and tribes so that you should get to know one another. In God's eyes, the most honoured of you are the ones most mindful of him: God is all knowing, all aware" (Al-Qur'an, 49:13). These verses make it clear that God created all human beings from Adam and Eve. Nor et al. (2018) maintains that these verses have expressed a comprehensive and unique concept of unity by emphasising the shared origin of mankind.

The Qur'anic teaching to know one another is an indication of interreligious dialogue. The single origin of humankind is the foundation of their equality (Kamali, 2009). In his farewell address, the Prophet of Islam said: "O people, your creator is One, and you are the descendants of the same father. So, no Arabs are superiors to the non-Arabs, neither white to the black nor black to the white except by the degree of righteousness" (Albani, 1996). The Qur'an asks Muslims to behave kindly with their neighbours irrespective of their religion (Al-Qur'an 4: 36). In his explanation of the verse, AlTabari (2000) clarifies that the neighbour in Islam includes both Muslims and non-Muslims. All have equal rights in Islam. The Qur'an reminds of the commonality among religions to establish cooperative and peaceful relations among the followers of different religions. The Qur'an says: "Say: O people of the Scripture! Come to a common word between us and you, that we worship none but Allah, and that we associate no partners with Him, and that none of us shall take others as lords besides Allah" (Al-Qur'an, 3:64). In his explanation, Duran (1998) remarks that the Qur'anic statement "come to a common word between us and you" provides a connotation of dialogue. He also argues that although the verse is specifically referring to the People of the Book, its application would be broader today. The Prophet of Islam also emphasised common beliefs while writing letters to non-Muslim rulers (Nor et al., 2018). In his letter to the kings of Abyssinia and Byzantine, the Prophet mentioned the aforementioned Qur'anic verse (AbuMunsher, 2007). 


\section{The Prophetic Approach to Interreligious Dialogue}

The Sunnah of Prophet Muhammad (PBUH) gives us numerous examples of dialogue and friendly conversation between Muslims and non-Muslims (Haq, 2014; Elius et al., 2019). The Prophet (PBUH) spent his life with people of different ideologies including believers, disbelievers, idolaters and atheists (Elius et al., 2019). He would maintain socio-economic relations with both Muslims and non-Muslims (Nor et al., 2018; Kurucan \& Erol). The current slogan "Love for all and hate for none" was rightly implemented by the Prophet (PBUH). That is why he disliked cursing even his enemies. This is evidenced when he went to the people of Ta'if to convey the message of Islam and was persecuted badly. Even after that, the Prophet did not curse them but prayed to God for their forgiveness (Galus, 2003). Another event is that a woman used to spread thorns on the street on which Prophet Muhammad (PBUH) would walk. The Prophet used to remove those thorns from the street while passing and never cursed or scolded her (Ibn Hajjaj n. d.; Nor et al., 2018). The Prophet set a model for all humanity (Kurucan \& Erol, 2012). He is reported to have said: "All creatures of God are the members of the family of God, and he is the best-loved of God who loves His creatures best (Al-Tabarani, n. d.).

Prophet Muhammad (PBUH) advised Muslims to exercise self-restraint while being abused verbally by non-Muslims. It is narrated by Urowah Ibn Zubair that "Once the Prophet of Islam was sitting with his wife, 'A'ishah, and a few companions. A group of Jews were passing them and said: 'Al-samu alaika' (May death be upon you). The Prophet kept silent and did not respond to the Jews. But, 'A'ishah, the wife of the Prophet, responded with anger by saying 'Alaikum wa la'natullah wa ghadaballahu 'alaikum (same to you as well as may Allah's curse and anger be upon you). On hearing this, the Prophet persuaded Aisha by saying that 'Allah loves gentleness' (Al- Bukhari, 2008). Nor et al. (2018) remarks that patience, self-restraint and gentleness are vital forces for strengthening human relationships in the society. The examples from the life of Prophet Muhammad (PBUH) can be enlightening for all people irrespective of their religion. 
The Prophet (PBUH) constantly thought of the welfare of all the creations of God. It is narrated that Nawwas Ibn Siman asked the Prophet (PBUH), what is a good deed? Then the Prophet replied, doing good to the creation of Allah (Ibn Hajjaj, n. d). The Prophet asked his companions to treat well the inhabitants of a land that enters under Muslim rule. Abu Dharr al- Ghifari reported that the Prophet of Islam said, one day you will conquer Egypt, and you must treat the people well therein (Ibn Hajjaj, n. d.). Taking care of the people around him was one of the highest priorities of the Prophet. The Prophet maintained an excellent relationship with his neighbours regardless of their ethnic and religious identities (Nor et al., 2018). He emphasised helping and supporting neighbours. Ibn Abbas reports that the Prophet (PBUH) said: He is not a true believer who eats with contentment (in full stomach) while his neighbours remain hungry by his side (Ali, 1981). This is evidenced by another hadith reported by Abdullah Ibn 'Amr that a sheep was slaughtered for him. He asked his slave, 'have you given some meat of the sheep to our Jewish neighbour? He repeated three times and said: I heard the Prophet of Allah saying that Jibril kept recommending to me to treat my neighbours in such a good way that I thought he would make them my heirs" (Al- Bukhari, 1989).

Abu Dharr al- Ghifari also narrated that the Prophet (PBUH) said: "O Abu Dharr! when you cook meat curry, give more water so that you can give something from it to your neighbour" (Ibn Hajjaj n. d.). In another narration, Abu Dharr al- Ghifari said that the Prophet of Islam advised me to give more water while cooking meat, then go and see every house of your neighbour and ensure something to each house (Ibn Hajjaj, n. d.). The above tradition makes it clear that the Prophet always considered the happiness of the neighbour. Sometimes people hesitate to give something to others if it is little. The Prophet encouraged them to give whatever they could afford. Abu Hurairah narrates that the Prophet (PBUH) said: "O Muslim women! Do not feel belittled in giving something to your neighbour if it is a very little amount" (Al- Bukhari in Mawsu'ah al- Hadith alSharif al-Kutub al-Sittah 2008). The Prophet of Islam strictly prohibited causing suffering to one's neighbour as he (PBUH) said: "He will not be a true believer, the Prophet repeated three times, 
from whose hand his neighbour is not safe" (Al- Bukhari in Mawsu'ah al- Hadith al- Sharif al-Kutub al-Sittah 2008).

The Prophet's tremendous respect and love for non-Muslims were reflected in the aftermath of the battle of Khaibar whereby the Prophet (PBUH) ordered his companions to return all the scriptures of the Jews (Nor et al. 2018). The Prophet (PBUH) also warned against those who treat a Dhimmi (non-Muslims living under Islamic state) unfairly. According to a narration by Safwan Ibn Sulaim, the Prophet of Islam said: "He who oppresses a Dhimmi or impose taxes beyond his ability or take something away from his possession without his permission I will stand against him in the Day of Judgement" (Abu Dawud, n.d.). In another tradition, the Prophet (PBUH) said: "He who hurts a Dhimmi, hurts me and who hurts me hurts Allah" (Albani, 1985). Thus, hurting the nonMuslims including Dhimmi is considered equally hurting Allah.

Imam Al- Qarafi as quoted in Abu- Munshar (2007) and Nor et al. (2018) stated that fair treatment (birr) to non-Muslims is as follows:

"Showing kindness to their weak and helping their poor and destitute, and feeding their hungry, clothing their necked, and uttering kind words to them from the position of grace and mercy and not from the position of fear and disgrace and removing their hardship as their neighbours if you (Muslims) have power to remove it, praying for their guidance so that they can become happy and fortunate people, giving them good advice in all their affairs - the affairs of this world and the hereafter and looking after their interest in their absence. If anyone hurts them and deprives them of their property or family, possessions or their rights, you should help them by removing their persecution and make sure to restore all their rights back to them".

The society established by the Prophet in Madinah is an example of peaceful co-existence. The community of Madinah was based on shared interest. The Charter of Madinah was formed to regulate every aspect of a citizenry regardless of religion. The Prophet mediated between Muslims and non-Muslims including Jewish, polytheistic and various ethnic groups of Madinah and established one ummah (Elius et al., 2019; Yitik, 2004; Nor et al., 2018). There was a common political, economic, legal, military and social entity 
within which they could co-exist peacefully while retaining their respective identities (Kurucan \& Erol, 2012). The charter was aimed to maintain peace and cooperation, protect the life and property of its inhabitants in Madinah, fight aggression and injustice irrespective of religious or tribal affiliation and ensure religious freedom. Muslims and Jews lived side by side in peace and harmony (Abu- Munshar, 2007; Elius et al., 2019; Nor et al., 2019).

The Prophet never compelled non-Muslim citizens to be administered by Islamic laws in Madinah. Abu Hurairah narrates that a group of Jewish religious scholars came to Muhammad (PBUH) and informed him that one of their fellow Jews committed adultery and they wanted him to issue a judgement. The Prophet (PBUH) judged the matter according to Jewish scripture (Al- Tabari, 2000). The Prophet (PBUH) made many other agreements with Jews, Christians and polytheists in addition to the Charter of Madinah. For example, the Prophet's (PBUH) agreement with the Najran Christians is a historical document of equal importance to the Charter of Madinah. According to the agreement:

'No clergy's or monk's post shall be changed, nobody shall be denied travel, their places of worship shall not be destroyed or turned into Islamic masjids or added to Muslims' buildings. ... If they (Christians) need help from Muslims with repairing their churches, monasteries or any other religious or worldly business, Muslims shall help them without placing them under any obligation; help and support for their religious needs shall be provided out of abiding by the promise of God's Messenger, as a donation and as God's grace" (Nor et al., 2018; Kurucan \& Erol, 2012).

Islamic history proves that interreligious dialogue started through this agreement between the Prophet of Islam and the delegation of Najran Christians in the very first century of the Hijrah (Karim \& Saile, 2009). Some commentators argue that the Muslims needed such an agreement because they were weak when they first migrated to Madinah and did not need it after the Islamic state was established. Such interpretations are weak when considering the relevant material from the Qur'an and Sunnah and relevant historical facts. The Prophet (PBUH) abided by all his agreements including the Madinah Charter unless they were violated by the other party, even during the most influential periods of the Islamic 
state (Kurucan \& Erol, 2012). The Prophet of Islam was always kind and sympathetic towards all humanity. When the Muslims conquered Makkah in $622 \mathrm{CE}$, the Makkan idolaters who persecuted the Prophet and his companions and compelled them to migrate to Madinah came under his (Prophet) complete control, yet instead of taking revenge, he declared amnesty for all (Esposito, 1988; Nor, 2011). The companions of the Prophet also grasped his ideals. History has produced evidence that non-Muslims received fair treatment in many Islamic societies. Their religious identities including temples, churches and synagogues were protected, and they could practice their religion freely (Nor, 2011; Elius et al., 2019).

\section{Conclusion}

In conclusion, diversity in Islam is part of God's plan for the benefit of mankind. Many Qur'anic verses emphasise justice and kindness in dealing with people of other religions. It also urges to cooperate and maintain harmonious relationships with one's neighbour irrespective of religion, culture and ideology. The Prophetic traditions also inspire Muslims to deal fairly and generously with non-Muslims including Jews, Christians, atheists and polytheists. The Prophet (PBUH) is a true example in engaging and maintaining interreligious dialogue and harmony with people of different religions. He made many accords with non-Muslims granting security of their life, property and religion and none of them was broken by him. He never harmed or abused non-Muslims, and strictly warned Muslims to refrain from any kind of harm to them. He advised Muslims to treat neighbours as their heirs. Accordingly, the Qur'anic teachings and Prophetic traditions could be a model for promoting interreligious dialogue and harmony. However, this will not work if Islam continues to be misunderstood. If the Qur'anic teachings and the Prophetic approach are understood and implemented correctly, religious conflicts, hatred, enmity and mistrust will be minimised, and interreligious harmony and peaceful co-existence will be established. 


\section{Acknowledgement}

This article is supported by UMRG grant no. RP035C-17HNE.

\section{References}

Abu- Munshar, M. Y. (2007). Islamic Jerusalem and its Christians: A history of tolerance and tensions. New York: Tauris Academic Studies.

Abu Dawud, S. (n. d.). Sunan Abi Dawud. Beirut: Al-Maktabah al'Asriyyah.

'Ali, A. (1981). Kanz al- 'Ummal fi Sunan al- Aqwal wa al- Af'al. Muassasah al-Risalah.

Albani, A. A. R. M. N. U. (1996). Silsilatu al-Ahadith al-Sahihah. Riyad: Maktabah al- Ma'arif,

Albani. A. A. R. M. N. U. (1985). Ghayatu al- Muram fi Takhrij Ahadis al- Halal wa al- Haram. Beirut: Al-Maktaba alIslam.

Al- Bukhari, A. A. M.I. I. (2000). Al- Bukhari in Mawsu'ah alHadith al-Sharif al-Kutub al-Sittah. Riyad: Dar al-Salam.

Al- Bukhari, A. A. M. I. I. (1989). Al-Adab al-Mufrad. Beirut: Dar al-Bashaer al- Islamiyyah.

Arinze, F. C. (1990). The Church in dialogue: Walking with other believers. San Francisco: Ignatius Press.

Al-Faruqi, I. R. (1998). Islam and other faiths. Leicester: The Islamic Foundation and the International Institute of Islamic Thought. 
Al-Masud A. and Elius M. (2016). The Qur'anic view of interreligious dialogue and harmony. International Journal of Recent Research in Social Sciences and Humanities, 3(1), 18-21.

Al- Qurtubi, A. A. M. (1964). Al-Jami' al-Ahkam al-Qur'an. (Tafsir al-Qurtubi). Cairo: Dar al- Qutb al Misriyyah.

Al- Tabarani, S. I. A. (n. d.). Al- Mu'jam al- Kabir. Cairo: Maktab Ibn Taymiyyah.

Al- Tabari, M. I. J. (2000). Jami' al-Bayan fi Ta'wil al-Qur'an. Beirut: Muassasah al- Risalah.

Al- Tirmidhi, M.I. I. (1975). Sunan al- Tirmidhi. Egypt: Sharikah Maktabahwa Matba'ah Mustafa Albani Al-Hobla.

Baker, O. (2006). The Qur'an on interfaith and inter-civilizational dialogue: Interpreting a divine message for twentieth century humanity. Kuala Lumpur: IIITM and ISUGO.

Considine, C. (2017). The racialization of Islam in the United States: Islamophobia, hate crimes, and flying while brown. Religions, 8(165), 1-19. doi: 10.3390/rel8090165.

Doron, A. (2019). Towards a Definition of Intercultural Dialogue. Retrieved from (http://www.eolss.net/samplechapters/c04/e1-39a-30).

Duran, K. (1998). The Drafting of Global Ethics: A Muslim Perspective. Global Dialogue Institute.

Elius, M. Khan, I. Nor, M. R. M. Yusoff, M. Y. Z. M. and Nordin, K. (2019). Islam as a religion of tolerance and dialogue. Journal for the Study of Religions and Ideologies, 18(52). 
Esposito, J. L. (1998). Mohammad and the Qur'an: Messenger and Message. In Islam: The Straight Path. London: Oxford University Press.

Gunaratna, R. (2015). Annual threat assessment: Global threat forecast. Counter Terrorist Trends and Analysis 7(1). Retrieved from (https://www.rsis.edu.sg/wpcontent/uploads/2015/01/CTTA-Jan_Feb-2015).

Galush, A. A. (2003). Sirah al-Nababiyyah wa al-Dawah Fi al-Ahd al-Makki, Beirut: Muassatu al- Risalah.

Hasan, A. H. (2011). An Islamic Perspective of Interfaith Dialogue amidst Current Inter-Religious Tensions Worldwide. Global Journal Al-Thaqafah, 1 (1), 25-35.

Hasan, M. H. (2009). Interpreting Islam and plural society. Islam and Civilizational Renewal. Kuala Lumpur: International Institute of Advanced Islamic Studies, 1(1), 99- 121.

Haq, M. Z. (2014). Muslim's participation in interfaith dialogue: Challenges and opportunity. Journal of Ecumenical Studies, 49 (4), 613-646.

Human Right Watch (2016). Retrieved from www.hrw.org.

Ibn Hajjaj, M. (n.d.). Sahih al-Muslim, in Mawsu'ah al-Hadith alSharif al-Kutub al-Sittah. Beirut: Dar al-Ihya' al-Turath al'Arabi.

Ibn Hisham, A. M. (1955). Sirah al-Nabawiyyah. Egypt: Sharikah Maktabah.

Ibn Kathir, A. F. I. (1988). Al-Bidayah wa al-Nihayah. Beirut: Dar al-Ihya' al-Turath.

Islam, K. N. (2010). World peace through interreligious dialogue. Paper presented in the 2nd International Conference on 
Interreligious and Intercultural Dialogue. Dhaka: University of Dhaka, November 27-29.

Kamali, M. H. (2009). Diversity and pluralism: A Qur'anic perspective. Islam And Civilizational Renewal, 1(1), 27- 54.

Karim, K. M. and Saile, S.A. (2009). Inter-faith dialogue: The Qur'anic and Prophetic perspective". Journal of Usuluddin. 29: 65-94.

Hambali, K. M. K. (2015). Dialogue of life: An experience in Leeds community". Journal of Usuluddin, 41: 147-167.

Kimball, C. (1991). Striving together: A way forward in ChristianMuslim relation. New York: Orbis Book.

Kurucan, A. \&Erol, M. K. (2012). Dialogue in Islam: Qur'anSunnah- History. London: Dialogue Society.

Humaid, S. B. (2010). Islam and dialogue with the other. In Interfaith Dialogue: Cross-Cultural Views (pp. 23-46). Riyad: Ghainaa Publication.

Lysack, M. (2006). Running head: Inner dialogue. Canadian Journal of Counselling, 40 (3), 131-144.

Mandour, T. M. (2010). Islam and religious freedom: Role of interfaith dialogue in promoting Global Peace. BYU Law Review, 2010 (3), 885-893.

Morgan, R. H. (2011). Peace among religions: Hans Kung's analysis of Christian and Muslim paradigms of social justice in search of global ethic. Forum on Public Policy. Retrieved from http://forumonpublicpolicy.com/vol2011 no3/archive/morga n.

Nor, M R M. Khan, I. Elius, M. (2018). Analysing the conceptual framework of religious freedom and interreligious 
relationship in Islam. Indonesian Journal of Islam and Muslim Societies. 8(2), 309-334. doi: 10.18326/ijims.v8i2.

Nor, M. R. M. (2011). Protecting non-Muslim: Its implementation during early Muslim rule of Islamicjerusalem. Al-Bayan: Journal of Qur'an and Hadith Studies. 9(1), 209-249.

Nor, M. R. M. (2012). Multicultural discourse from the Minbur: A study on khutbah texts Prepared by Jakim Malaysia. In Fukami Naoko and Sato Shohei, Islam and multiculturalism: between norms and forms, (pp. 55-62). JSPS Asia and Africa Science Platform Program, Waseda University, Tokyo, Japan.

Shehu, F. M. (2008). Nostra Aetate and inter-religious dialogue: An Islamic perspective. Selagor: International Islamic University Press.

Senin, N. Hambali, K. M. K. Ramlan, S.F. (2013). Al-Biruni's India: A model of comparative study. In Omar, N. Sintang, S. and Damit, S. AG (Eds.), Wakana Kontemporari Islam. Penerbit Universiti Malaysia Sabah.

Sintang, S. Baharuddin, A. Hambali, K. M. K. (2012). Dialogue of life and its significance in interreligious relation in Malaysia. International Journal of Islamic Thought 2: 69-78.

Swamy, M. (2012). Religion, religious conflicts and interreligious dialogue in India: An interrogation. $\mathrm{PhD}$ Thesis, University of Edinburgh, Edinburgh.

Swidler, L. (2014). The dialogue decalogue: Ground rules for interreligious dialogue. In Dialogue for interreligious understanding: Strategies for the transformation of cultureshaping institution. (Ed.), (pp. 47-52). New York: Palgrave Macmillan. 
Tan, P. (2001). Divine qualities of spiritual dialogue. Singapore Bahai Studies Review 6:109-127.

Wani, H. Abdullah, R. and Chang, L.W. (2015). An Islamic perspective in managing religious diversity. Religions 6, 642-656. doi: 10.3390/rel6020642.

Yitik, A. I. (2004). Islam and pluralism: Does Qur'an approve pluralism. Journal of Religious Culture. Retrieved from http://web.uni-frankfurt.de/irenik/relkultur68f.

Zewail, A. (2006). Dialogue of civilizations: making history through a new world vision. In Jean Staune (Ed.) Science \& the Search for Meaning: Perspective from International Scientists (pp.90-106). Philadelphia and London: Templeton Foundation Press. 